Louisiana State University

LSU Digital Commons

Faculty Publications

Department of Chemistry

$1-1-2019$

\title{
Synthesis and investigation of phthalocyanine-biotin conjugates
}

\author{
M. Graca H. Vicente \\ Louisiana State Univ, Dept Chem, vicente@lsu.edu \\ Elizabeth A. Okoth \\ Louisiana State Univ, Dept Chem \\ Zehua Zhou \\ Louisiana State Univ, Dept Chem \\ Benson Ongarora \\ Louisiana State Univ, Dept Chem
}

Follow this and additional works at: https://digitalcommons.Isu.edu/chemistry_pubs

Part of the Chemistry Commons

\section{Recommended Citation}

Vicente, M. Graca H.; Okoth, Elizabeth A.; Zhou, Zehua; and Ongarora, Benson, "Synthesis and investigation of phthalocyanine-biotin conjugates" (2019). Faculty Publications. 34.

https://digitalcommons.Isu.edu/chemistry_pubs/34

This Article is brought to you for free and open access by the Department of Chemistry at LSU Digital Commons. It has been accepted for inclusion in Faculty Publications by an authorized administrator of LSU Digital Commons. For more information, please contact gcoste1@lsu.edu. 


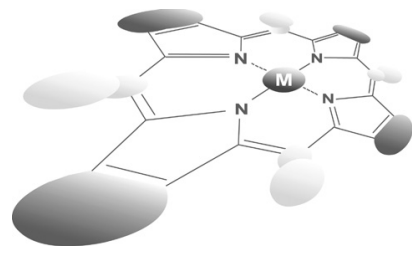

\title{
Synthesis and investigation of phthalocyanine-biotin conjugates
}

\author{
Elizabeth A. Okoth ${ }^{a}$, Zehua Zhou ${ }^{a}$, Benson Ongarora ${ }^{a}$, Alyssa Stutes ${ }^{a}$, \\ J. Michael Mathis ${ }^{b}$ and M. Graça H. Vicente ${ }^{a *}$
}

\author{
${ }^{a}$ Department of Chemistry, Louisiana State University, Baton Rouge, LA 70803, USA \\ ${ }^{\mathrm{b}}$ Department of Comparative Biomedical Sciences, Louisiana State University School of Veterinary Medicine, \\ Baton Rouge Louisiana 70803, USA
}

This paper is part of the 2019 Women in Porphyrin Science special issue.

Received 14 December 2018

Accepted 15 January 2019

\begin{abstract}
An isothiocyanato-functionalized phthalocyanine (Pc) was synthesized in good yield from the corresponding amine-substituted Pc. This Pc reacted with ethanolamine, biotin hydrazine, and biotin diethylamine under mild conditions (room temperature in DMF or DMSO in the presence of TEA) to produce the corresponding thiourea products in $60-75 \%$ yields. All Pcs showed intense Q absorptions in DMF around $677 \mathrm{~nm}$, emissions centered at $683 \mathrm{~nm}$, and fluorescence quantum yields in the range 0.18-0.27. The Pcs were phototoxic to human carcinoma HEp2 cells $\left(\mathrm{IC}_{50} \sim 7\right.$ at $\left.1.5 \mathrm{~J} / \mathrm{cm}^{2}\right)$ and localized in multiple organelles, including the lysosomes, Golgi and ER. One biotin-Pc conjugate was injected via tail vein into nude mice bearing HT-29 tumors and demonstrated selective localization in the tumor tissue.
\end{abstract}

KEYWORDS: phthalocyanine, isothiocyanate, biotin, photosensitizer, PDT.

\section{INTRODUCTION}

Phthalocyanines (Pcs) are efficient photosensitizers (ps) for the treatment of cancers by photodynamic therapy (PDT) [1]. PDT is a minimally invasive treatment that uses light, a ps and molecular oxygen to selective destroy malignant tissues via the generation of singlet oxygen $\left({ }^{1} \mathrm{O}_{2}\right)$ and reactive oxygen species (ROS). Photosens, a silicon(IV)Pc, and CGP55847, a zinc(II)Pc, are used clinically for the treatment of breast, gastrointestinal, and squamous cell carcinoma of the upper aerodigestive tract [2-4]. Pcs are an excellent choice as ps due to their strong absorbance in the near-infrared spectral region $(>670 \mathrm{~nm})$ where light penetrates deeply through the skin, their high chemical and photo-stability, in addition to being excellent singlet oxygen generators [5-7]. However, Pcs generally have poor solubility in

*Correspondence to: M. Graça H. Vicente, tel: +225-578-7405, email: vicente@1su.edu. water and most organic solvents, which limits their purification and applications. Strategies used to address the poor solubility of Pcs include the introduction of bulky or water-solubilizing substituents, and the use of isomeric mixtures of compounds [4, 8-13]. Since the use of isomeric Pc mixtures can lead to reproducibility challenges, synthesis of isomerically pure compounds is a more desirable approach. In particular, isomerically pure Pcs bearing versatile functional groups can be used as templates to produce functionalized Pcs via, for example, esterification, substitution and acylation reactions [11-19]. The Pc templates can be conjugated to hydrophilic and cell-targeting moieties, yielding amphiphilic compounds with enhanced solubility, serum life, and specificity towards receptors overexpressed on cancer cells [11, 14, 20-22]. This strategy is particularly useful when the required precursors bearing targeting moieties are not readily available or are unstable under cyclization conditions [23-24]. The conjugation of tumor-cell-targeting moieties to Pc templates has been 
reported to improve the tumor specificity and uptake of Pc macrocycles [5, 9, 11, 20, 25-28]. However, some targeting agents, particularly those of high molecular weight, may trigger an immunogenic response [29]. Therefore, small tumor-targeting substituents such as low molecular weight PEG groups, peptides, and vitamins, including folic acid, riboflavin, vitamin B-12 and biotin, have been investigated as targeting moieties and have been shown to increase tumor selectivity and uptake into cancer cells [12, 25, 29-34]. Several cancer cell lines overexpress folate receptors, vitamin B-12 receptors and biotin receptors. Studies conducted on leukemia, ovarian, colon, mastocytoma, lung, renal, and breast cancer cell lines showed enhanced uptake of biotin conjugates compared to folate and vitamin B-12 conjugates [29]. Meerovich et al. reported that a biotin-containing Photosens showed higher photodynamic efficacy compared with the parent drug [35]. Photosens, however, is a mixture of isomers. Herein, we report the synthesis of an isomerically pure biotin-containing $\mathrm{Pc}$, via reaction on a $\mathrm{Pc}$ template bearing an amine reactive isothiocyanato group. The conjugation of porphyrins, chlorins, bacteriochlorins and BODIPYs to various targeting molecules via an isothiocyanate functional group under mild conditions generally yields the targeted conjugates in short reaction times and high yields [36-41]. Duan et al. [11], LopezDuarte et al. [17], and Hammer et al. [16], have reported the conjugation of isothiocyanate-functionalized Pcs to monoclonal antibodies, aluminosilicate Zeolite $\mathrm{L}$ and oligonucleotides, respectively. We report the synthesis of a regioisomerically pure isothiocyanate-functionalized Pc and its conjugation to biotin hydrazine and biotin diethylamine [42]. The spectroscopic and biological properties of the conjugates were evaluated and compared to those of the unconjugated Pc.

\section{RESULTS AND DISCUSSION}

\section{Synthesis}

Scheme 1 shows the synthetic route to isothiocyanatefunctionalized Pc 4. The precursor, 3- $N$-Boc-aminophenol phthalonitrile 1, was prepared according to our previously reported procedure [43]. Initial attempts to prepare the Boc-protected Pc 2 using various phthalonitrile ratios ranging from 1:3 to 1:9 led to formation of mixtures of Pc isomers. Such low ratios of phthalonitriles in cross condensation reactions are known to lead to mixtures of regioisomeric Pcs due to the interactions between the different phthalonitriles leading to the formation of adj- and opp- $\mathrm{A}_{2} \mathrm{~B}_{2}, \mathrm{~A}_{3} \mathrm{~B}$ and $\mathrm{AB}_{3}$-type Pcs, in addition to the $A_{4}$ and $B_{4}$ Pcs in a single reaction vessel. These isomers are difficult to separate chromatographically due to their similar $R_{\mathrm{f}}$ values. However, using a large excess of one phthalonitrile (A) favors the formation of only $A_{3} B$ and $A_{4}$ Pcs [18-19]. Therefore, the targeted $\mathrm{A}_{3} \mathrm{~B}$-type Pc 2 was synthesized using a 30-fold excess of unsubstituted phthalonitrile, and easily separated from the single byproduct $\mathrm{A}_{4} \mathrm{Pc}$ due to the low solubility<smiles>CC(C)(C)OC(=O)Nc1ccc(Oc2cccc(C#N)c2C#N)cc1</smiles>

1
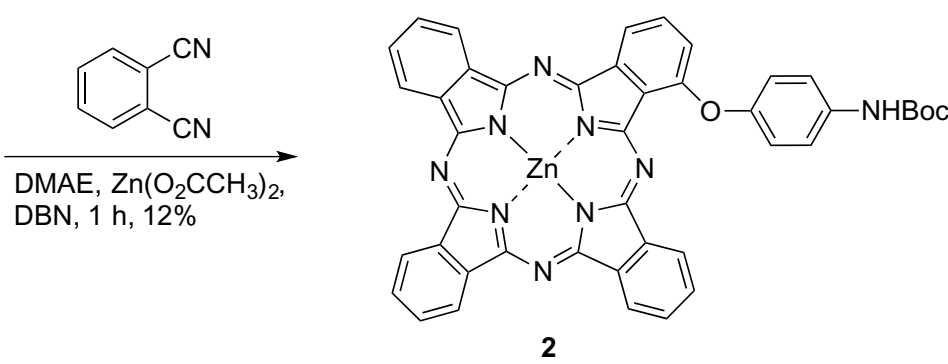

TFA/DCM, $4 \mathrm{~h}$ $0{ }^{\circ} \mathrm{C}, 99 \%$

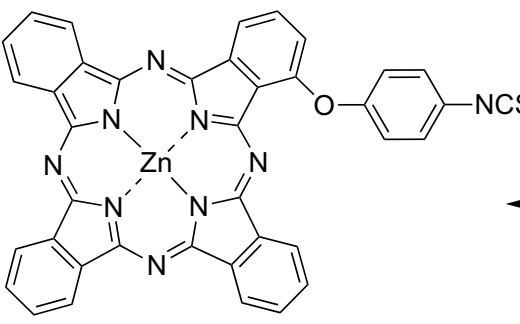

4
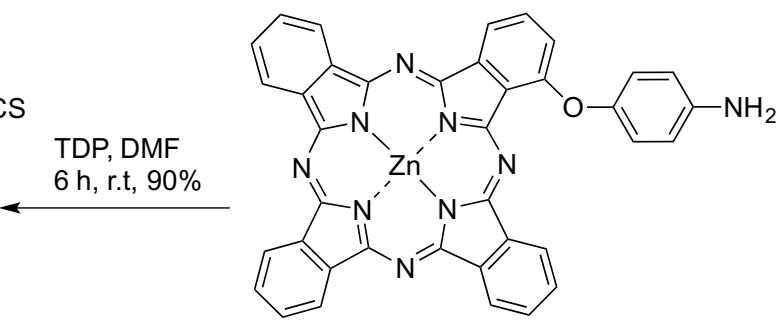

3

Scheme 1. Synthetic route to Pc-NCS 4 
of the latter Pc. The condensation occurred in the presence of zinc(II) acetate and a catalytic amount of 1,5-diazabicyclo[4.3.0]non-5-ene $(\mathrm{DBN})$ as base in dimethylethanolamine(DMAE) at $140^{\circ} \mathrm{C}$ for $1 \mathrm{~h}$. Pc 2 was isolated in $12 \%$ yield after separation from the unsubstituted $\mathrm{A}_{4}$ Pc by filtration, followed by re-crystallization. Pc 2 bearing a Boc-protected aminophenoxy $\alpha$-substituent shows increased solubility compared with the unsubstituted $\mathrm{A}_{4} \mathrm{Pc}$ and decreased tendency for aggregate formation.

Pc 2 was quantitatively deprotected using trifluoroacetic acid (TFA) in dichloromethane at $0{ }^{\circ} \mathrm{C}$ to give $\mathrm{Pc}$ 3. The amine group on Pc $\mathbf{3}$ was converted to the isothiocyanate functional group in Pc 4 using 1,1'thicarbonyldi-2(1H)-pyridone (TDP) in anhydrous DMF, as shown in Scheme 1, using a procedure similar to that previously reported [36, 42]. Pc 4 was obtained in $90 \%$ yield. The isothiocyanate functional group is highly reactive toward amines, producing the corresponding thioamide addition products under mild conditions in high yields.

Pc 4 reacted with ethanolamine in the presence of triethylamine (TEA) as base, at room temperature for $30 \mathrm{~min}$, to produce hydroxyl Pc 5 in $66 \%$ yield, as shown in Scheme 2. Biotin ethylenediamine was synthesized by activation of the carboxylate group with EDCI and HOBt in DMSO, followed by reaction with $N$-Boc ethylenediamine in a 1:1 ratio, as previously reported [44]. Deprotection of the Boc group using TFA in dichloromethane for $2 \mathrm{~h}$ at $0^{\circ} \mathrm{C}$ gave biotin ethylenediamine. Optimal reaction conditions for the conjugation of Pc 4 with biotin hydrazine and biotin ethylenediamine were found to be a $1: 1$ reaction ratio using TEA as the base, in DMSO over $2 \mathrm{~h}$, to give Pc 6 and Pc 7 in 60-75\% yields, as shown in Scheme 2.

The structures of all Pcs were characterized by ${ }^{1} \mathrm{H}-$ and ${ }^{13} \mathrm{C}-\mathrm{NMR}$ spectroscopy and by MALDI-TOF mass spectrometry (see Supporting information).

\section{Spectroscopic properties}

The spectroscopic properties for Pcs 4, 5, 6 and 7 in DMF are summarized in Table 1 and their absorption spectra are shown in Fig. 1. The absorption spectra of the Pcs in DMF displayed a characteristic Q band $\left(\pi-\pi^{*}\right.$

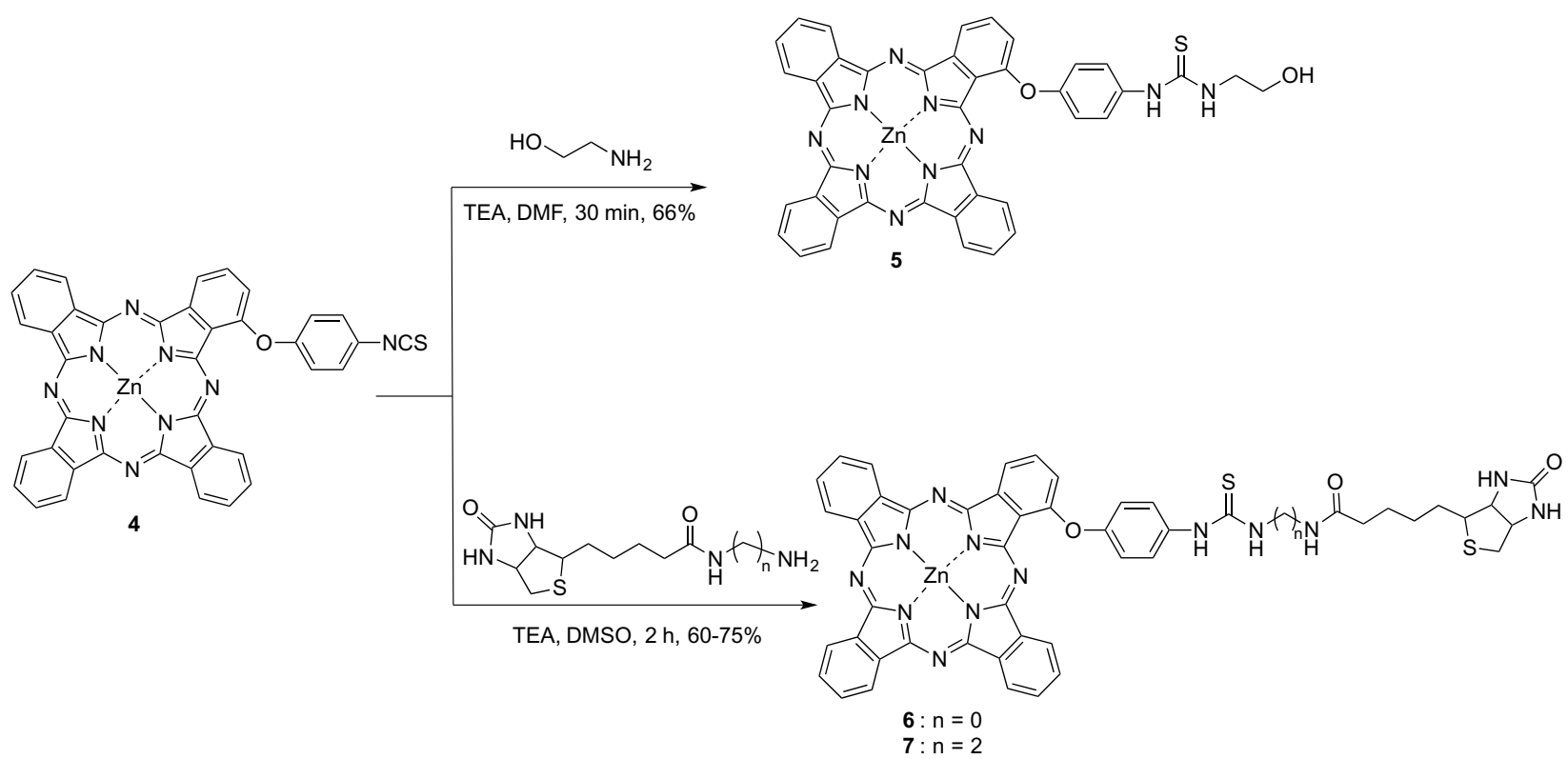

Scheme 2. Reactions of Pc-NCS 4

Table 1. Spectroscopic properties for Pcs 4, 5, 6, and 7 in DMF at room temperature

\begin{tabular}{ccccc}
\hline Pc & Absorption $\left(\lambda_{\max }, \mathrm{nm}\right)$ & Emission $^{\mathrm{a}}\left(\lambda_{\max }, \mathrm{nm}\right)$ & $\log \varepsilon(\mathrm{nm})$ & $\Phi_{\mathrm{f}}^{\mathrm{b}}$ \\
\hline $\mathbf{4}$ & 677 & 682 & 5.00 & 0.26 \\
$\mathbf{5}$ & 678 & 684 & 4.95 & 0.27 \\
$\mathbf{6}$ & 674 & 682 & 4.85 & 0.18 \\
$\mathbf{7}$ & 678 & 684 & 4.80 & 0.19 \\
\hline
\end{tabular}

${ }^{\mathrm{a}}$ Excitation at $635 \mathrm{~nm} ;{ }^{\mathrm{b}}$ calculated using $\mathrm{Zn}\left(\Phi_{\mathrm{f}}=0.17\right)$ as the Ref. [45] 


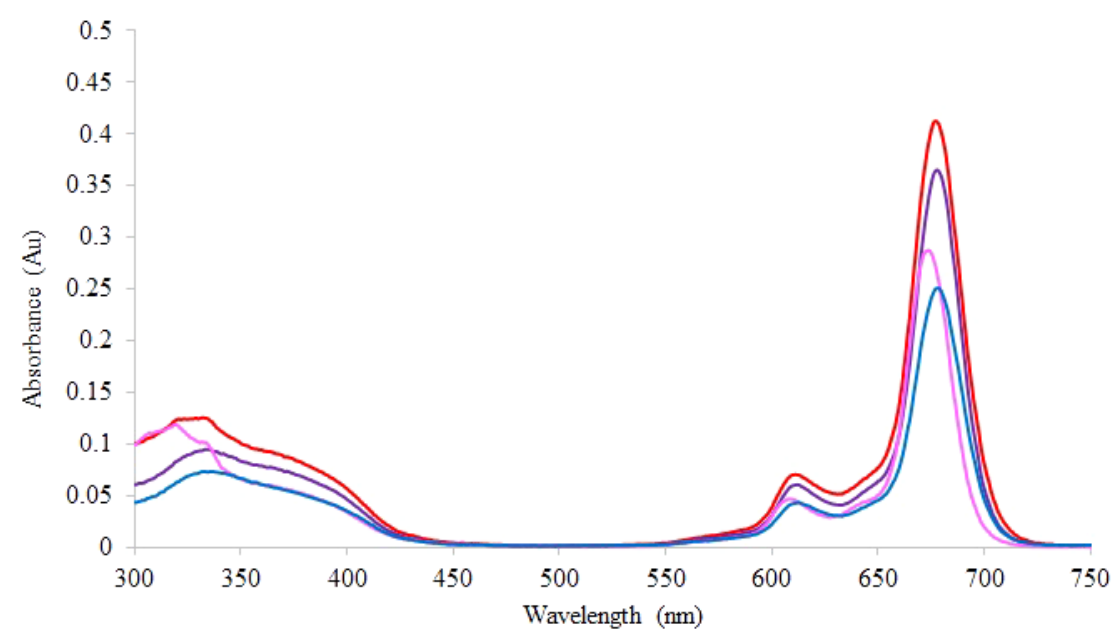

Fig. 1. Absorption spectra of Pcs 4 (red), 5 (purple), 6 (pink), and 7 (blue) at $4 \mu \mathrm{M}$ concentration in DMF at room temperature

Table 2. Cytotoxicity (CTB assay, light dose $\sim 1.5 \mathrm{~J} / \mathrm{cm}^{2}$ ) and comparative uptake for Pcs in HEp2 cells

\begin{tabular}{cccc}
\hline Pc & Dark toxicity $\mathrm{IC}_{50}(\mu \mathrm{M})$ & Phototoxicity $\mathrm{IC}_{50}(\mu \mathrm{M})$ & Uptake ratio at $24 \mathrm{~h}^{\mathrm{a}}$ \\
\hline $\mathbf{4}$ & $>200$ & 70 & 1 \\
$\mathbf{5}$ & $>200$ & 7 & 8 \\
$\mathbf{6}$ & $>200$ & 9 & 4 \\
$\mathbf{7}$ & $>200$ & 6.5 & 5 \\
\hline
\end{tabular}

${ }^{a}$ Relative to $4(\mathrm{Pc} / \mathrm{Pc} 4)$.

transition) between 674 and $678 \mathrm{~nm}$ and a Soret band between 300 and $400 \mathrm{~nm}$. The spectra followed the BeerLambert law at concentrations between 2 and $10 \mu \mathrm{L}$ (see Supporting information). The fluorescence emissions appeared between 682 and $684 \mathrm{~nm}$, and the fluorescence quantum yields ranged from $0.18-0.27$. The biotin-Pc conjugates displayed lower fluorescence quantum yields than Pcs $\mathbf{4}$ and 5, maybe due to the higher flexibility of the conjugates which tend to increase non-radiative decay to the ground state.

\section{Cellular studies}

The cellular properties of Pcs 4, 5, 6 and 7, including their time-dependent cellular uptake, cytotoxicity and intracellular localization, were investigated in human carcinoma HEp2 cells, and the results are summarized in Table 2, Figs 2-6, and the Supporting information. For uptake studies, the HEp2 cells were incubated with $10 \mu \mathrm{M}$ solutions of each Pc and the extent of uptake determined after 1, 2, 4, 8 and $24 \mathrm{~h}$ (Fig. 2). The isothiocyanate-Pc 4 showed lower uptake at all time points investigated compared to the hydroxy-Pc 5 and biotin conjugates $\mathbf{6}$ and 7. On the other hand, Pc 5 showed the highest uptake of all Pcs at all time points, and after $24 \mathrm{~h}$ accumulated within cells 8 times more than Pc 4. This might be due to its lower molecular weight and favorable amphiphilicity. The two biotin-containing Pcs 6 and 7 showed similar cellular uptake, and after $24 \mathrm{~h}$ were found within cells 4 and 5 times more than Pc 4, respectively.

The organelle-specific fluorescence probes BODIPY Ceramide (Golgi), Lyso-Sensor Green (lysosomes), MitoTracker Green (Mitochondria), and ER Tracker Blue/ White (ER) (Invitrogen) were used in co-localization experiments. The red color indicates the Pc, the purple/ pink and orange/yellow colors indicate co-localization of the Pc and organelle probes in Figs 3-6. All Pcs localized in the ER, Golgi apparatus, and lysosomes (Table 3). In addition, to a small extent Pc $\mathbf{5}$ was also found in the mitochondria. The biotinylated Pcs 6 and 7 showed similar localization in the lysosomes and the Golgi apparatus, with Pc 7 appearing to have enhanced localization in the ER compared with Pc 6.

The dark toxicity and phototoxicity of the Pcs were investigated using Promega's Cell Titer Blue viability assay. None of the Pcs was toxic in the dark up to $200 \mu \mathrm{M}$ concentration. However, upon exposure to a low light dose $\left(\sim 1.5 \mathrm{~J} / \mathrm{cm}^{2}\right)$, all Pcs were phototoxic, particularly Pcs 5-7, with determined $\mathrm{IC}_{50}$ values (50\% inhibition of cell proliferation based on dose-response curves) of 70, 7, 9 and $6.5 \mu \mathrm{M}$ for Pcs 4, 5, 6 and 7, respectively. 


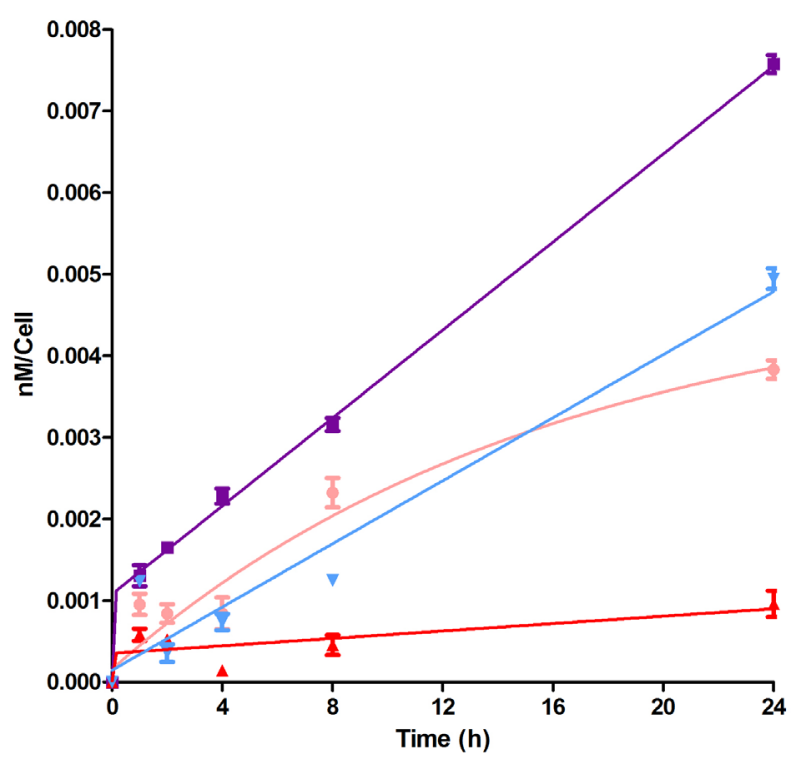

Fig. 2. Time-dependent uptake of Pcs 4 (red), 5 (purple), 6 (pink), and 7 (blue) at $10 \mu \mathrm{M}$ by human carcinoma HEp2 cells

Since all Pcs showed similar intracellular distributions, this result may be due to the lower cellular uptake of Pc $\mathbf{4}$ into cells. The most phototoxic Pc was biotin conjugated Pc 7, probably due to its increased localization in the ER compared with all other Pcs.

\section{In vivo studies}

The biotin-Pc conjugate 6 was selected based on the in vitro studies, for preliminary investigation in nude mice bearing human HT-29 colorectal tumors. In this experiment, Pc 6 was injected via tail vein into mice with subcutaneous tumors of approximately $5 \mathrm{~mm}$ in diameter. Post-injection, the mice were anesthetized and imaged using an excitation wavelength of $640 \mathrm{~nm}$ and an emission wavelength of $710 \mathrm{~nm}$, at various time intervals for up to $120 \mathrm{~h}$. As shown in Fig. 7a, systemic fluorescence of Pc $\mathbf{6}$ was observed in a representative mouse as early as $3 \mathrm{~h}$ post-injection, and selective localization was seen within tumors by $6 \mathrm{~h}$ after administration. Detection persisted through $48 \mathrm{~h}$ at the tumor site but declined after 72 and $120 \mathrm{~h}$. However, non-specific background expression was also detected in the peritoneal region at each time point. After the final imaging scan, the mice were euthanized, and the organ and tumor tissues were harvested. Fluorescence analysis of tumor tissue from a representative mouse showed high levels of localization of Pc $\mathbf{6}$, as well as high levels in the kidneys, peritoneal fat, and uterus (Fig. 7b). Lower levels of Pc $\mathbf{6}$ were also detected in pancreas, liver, lungs, and intestines, while there was no detectable Pc $\mathbf{6}$ in either heart or spleen.

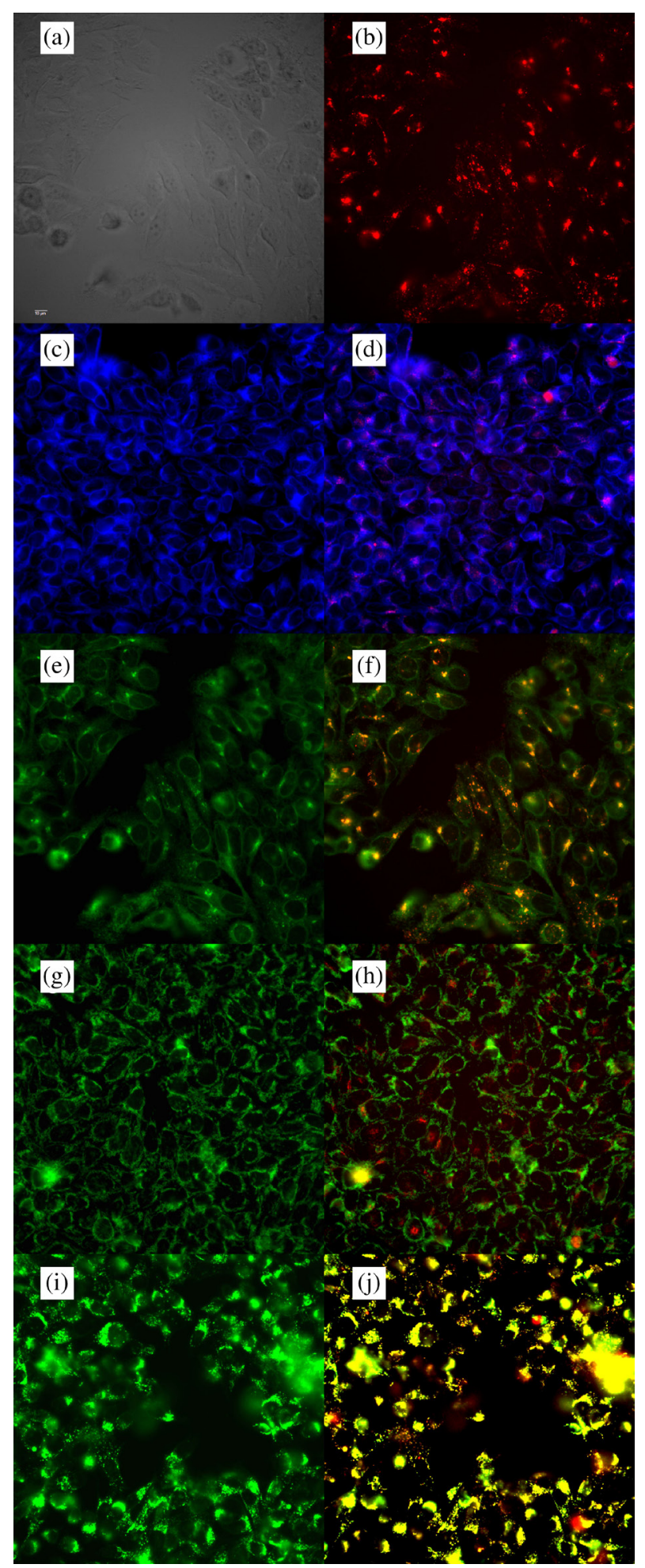

Fig. 3. Subcellular localization of Pc 4 in HEp2 cells at $10 \mu \mathrm{M}$ for $6 \mathrm{~h}$. (a) Phase contrast (b) Overlay and fluorescence of Pc 4 (c) ER tracker Blue/White fluorescence (e) MitoTrack green fluorescence (g) BODIPY ceramide (i) LysoSensor green fluorescence $(d, f, h, j)$ overlays of tracers with Pc 4 fluorescence. Scale bar: $10 \mu \mathrm{m}$ 


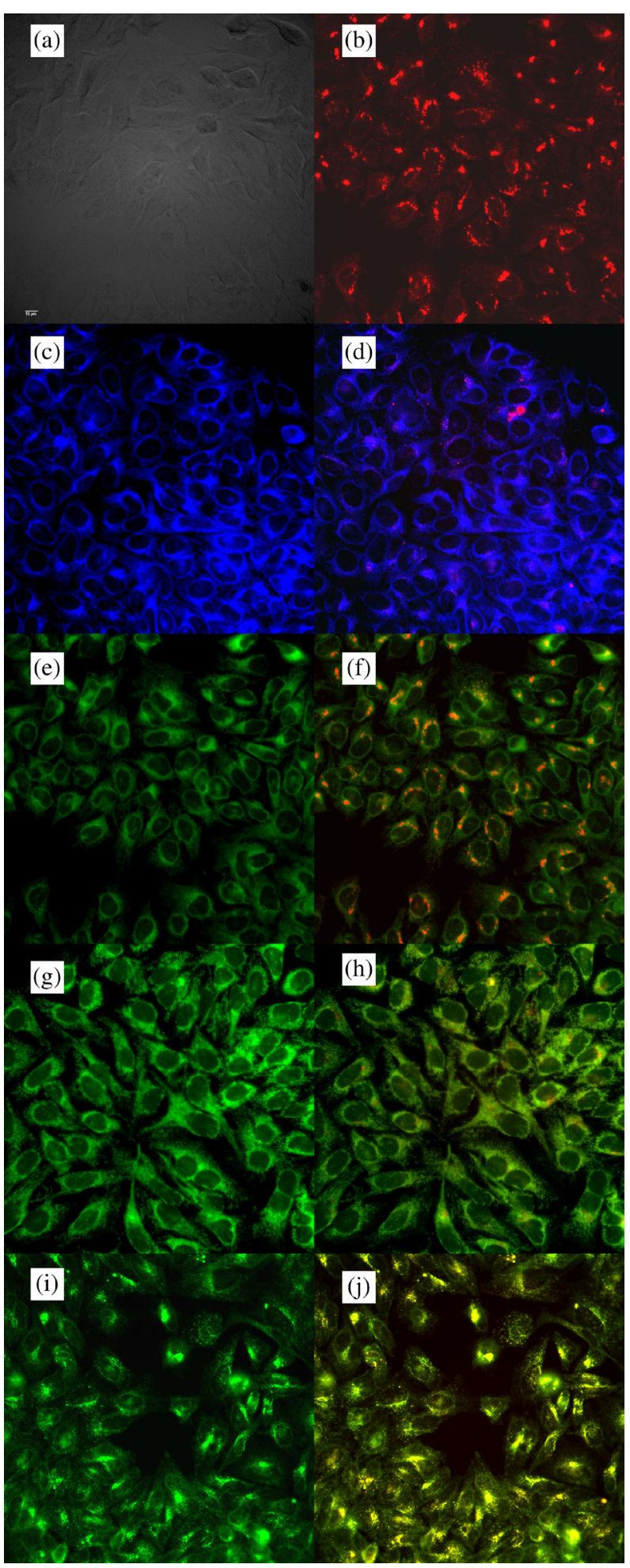

Fig. 4. Subcellular localization of Pc 5 in HEp2 cells at $10 \mu \mathrm{M}$ for $6 \mathrm{~h}$. (a) Phase contrast (b) Overlay and fluorescence of Pc 5 (c) ER tracker Blue/White fluorescence (e) MitoTrack green fluorescence (g) BODIPY ceramide (i) LysoSensor green fluorescence (d, f, h, j) overlays of tracers with Pc 5 fluorescence. Scale bar: $10 \mu \mathrm{m}$

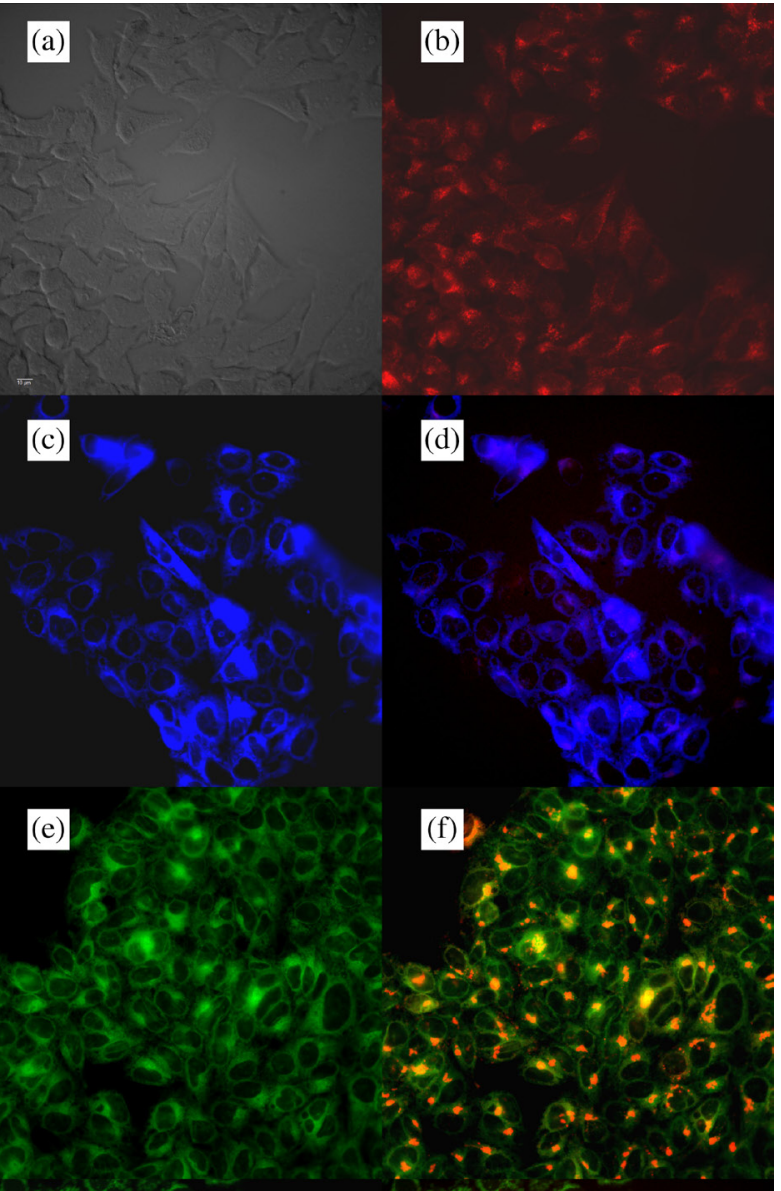

(g)

(h)

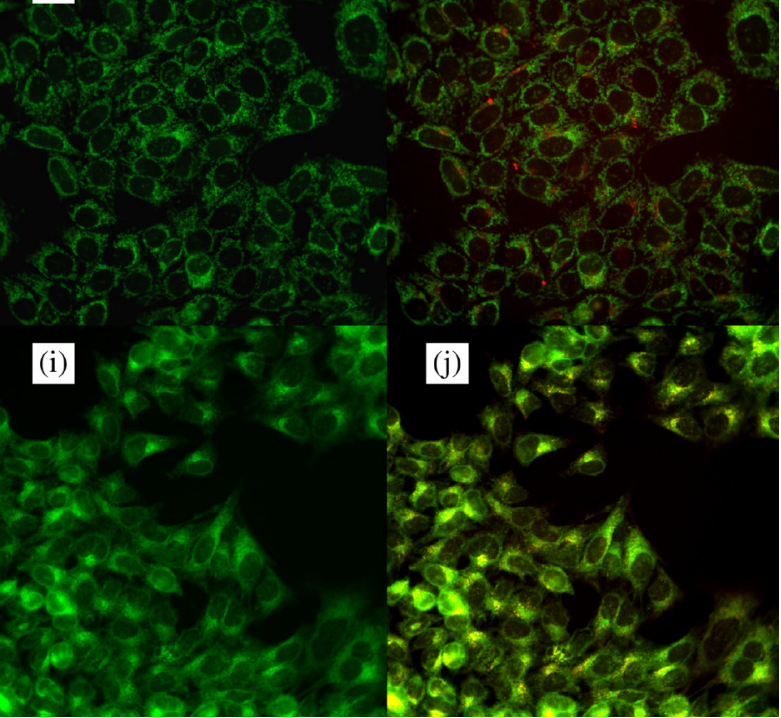

Fig. 5. Subcellular localization of Pc 6 in HEp2 cells at $10 \mu \mathrm{M}$ for 6 h. (a) Phase contrast (b) Overlay and fluorescence of Pc 6 (c) ER tracker Blue/White fluorescence (e) MitoTrack green fluorescence (g) BODIPY ceramide (i) LysoSensor green fluorescence $(d, f, h, j)$ overlays of tracers with Pc 6 fluorescence. Scale bar: $10 \mu \mathrm{m}$ 


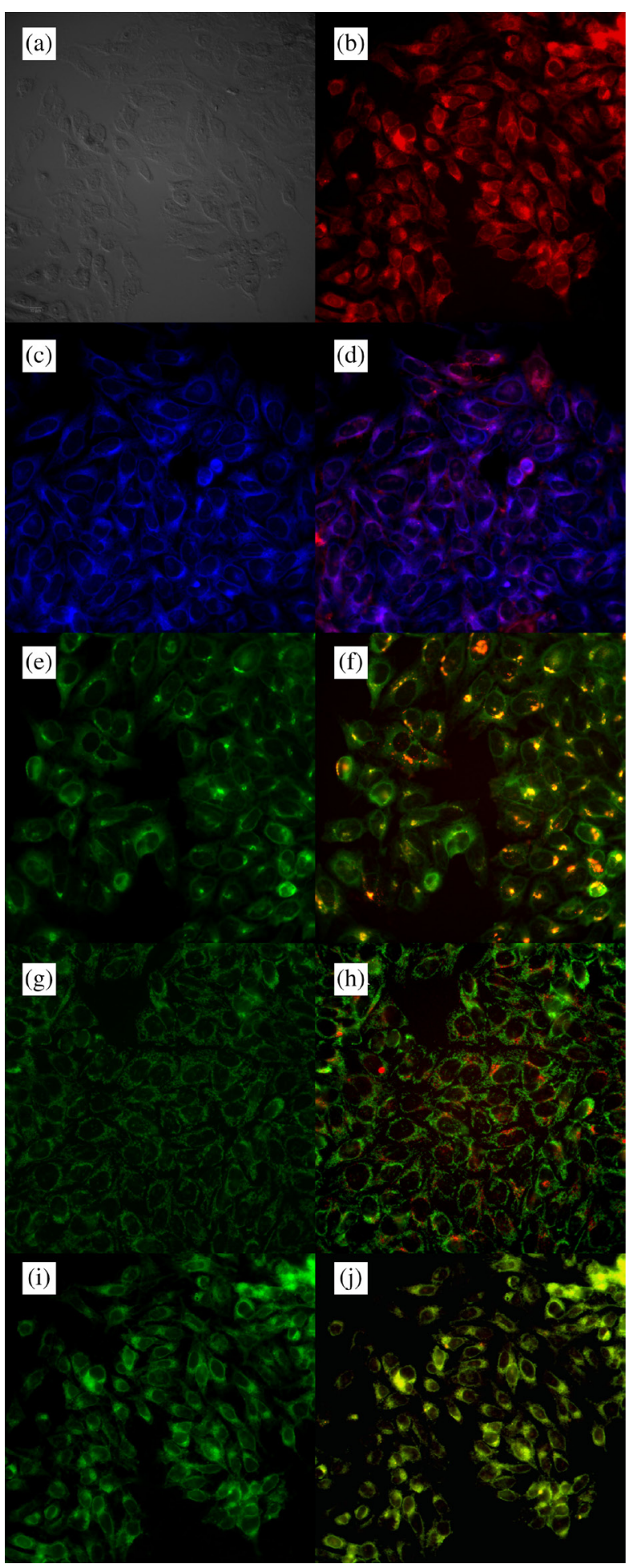

Fig. 6. Subcellular localization of Pc 7 in HEp2 cells at $10 \mu \mathrm{M}$ for 6 h. (a) Phase contrast (b) Overlay and fluorescence of Pc 7 (c) ER tracker Blue/White fluorescence (e) MitoTrack green fluorescence (g) BODIPY ceramide (i) LysoSensor green fluorescence $(\mathrm{d}, \mathrm{f}, \mathrm{h}, \mathrm{j})$ overlays of tracers with Pc 7 fluorescence. Scale bar: $10 \mu \mathrm{m}$

\section{EXPERIMENTAL}

\section{Synthesis}

General. All reagents and solvents were purchased from commercial sources and used directly without purification. Analytical thin-layer chromatography (TLC) was performed using plastic backed TLC plates 254 (precoated, $200 \mu \mathrm{m}$ ) from Sorbent Technologies to monitor the reactions. Silica gel $60(230 \times 400$ mesh $)$ was used for column chromatography. NMR spectra were obtained on an AV-III-400-NanoBay Bruker spectrometer (400 MH for ${ }^{1} \mathrm{H}, 100 \mathrm{MHz}$ for ${ }^{13} \mathrm{C}$ ). Chemical shifts are reported in $\delta(\mathrm{ppm})$ relative to DMF- $d 78.03 \mathrm{ppm}\left({ }^{1} \mathrm{H}\right)$, $163.15 \mathrm{ppm}\left({ }^{13} \mathrm{C}\right)$; THF- $d_{8} 3.58 \mathrm{ppm}\left({ }^{1} \mathrm{H}\right), 67.57 \mathrm{ppm}$ $\left({ }^{13} \mathrm{C}\right)$; DMSO- $d_{6} 2.5 \mathrm{ppm}\left({ }^{1} \mathrm{H}\right), 39.51 \mathrm{ppm}\left({ }^{13} \mathrm{C}\right)$. An $\alpha$-Cyano-4-hydroxycinnamic acid matrix was used for MALDI-TOF mass spectra measurements on a Bruker ProFlex III spectrometer. Melting points were measured using a Barnstead Electrothermal Mel-Temp 1101D Capillary Melting Point Apparatus. Phthalonitrile 1 was synthesized as previously reported. ${ }^{43}$

$P \boldsymbol{c}$ 2. A mixture of 3-(4- $\mathrm{N}$-Boc-aminophenol) phthalonitrile $\left(0.03 \mathrm{~g}, 8.95 \times 10^{-2} \mathrm{mmol}\right)$, phthalonitrile $(0.34 \mathrm{~g}, 2.68 \mathrm{mmol})$, and zinc(II) acetate $(1.52 \mathrm{~g}$, $0.69 \mathrm{mmol})$ dissolved in DMAE $(6.0 \mathrm{~mL})$ was heated at $140{ }^{\circ} \mathrm{C}$ with two drops of DBN under argon for $1 \mathrm{~h}$. The solvent was removed under reduced pressure and the crude mixture was filtered using acetone. The product was further purified by silica gel column chromatography column to give Pc $\mathbf{2}$, a blue solid eluted using dichloromethane/methanol (95:5). Pc 2 was dried under vacuum for 2 days to give a blue solid in $12 \%$ yield. M.p.: $210^{\circ} \mathrm{C} .{ }^{1} \mathrm{H}$ NMR $\left(\mathrm{THF}-\mathrm{d}_{8}, 400 \mathrm{MHz}\right.$ ): 7.8-7.75 (m, 2H, Ar-H), 7.63-7.61 (m, 2H, Ar-H), 7.197.14 (m, 2H, Ar-H), 6.97-6.92 (m, 6H, Ar-H), 6.82-69 (m, 6H, Ar-H), $2.06\left(\mathrm{C}\left(\mathrm{CH}_{3}\right)_{3}\right) .{ }^{13} \mathrm{C}$ NMR $\left(\mathrm{DMF}^{\mathrm{d}} \mathrm{d}_{7}\right.$, $100 \mathrm{MHz}): 212.43(\mathrm{C}=\mathrm{O}), 208.9,168.8,167.3,155.0$, $153.8,153.5,153.4,149.8,138.9,137.2,136.6,135.5$, 129.2, 122.6, 122.4, 120.6, 119.8, 118.6, 117.0, 79.3,

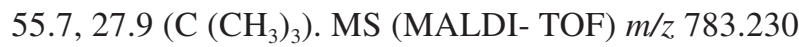
$[\mathrm{M}]^{+}$, calcd for $\mathrm{C}_{43} \mathrm{H}_{29} \mathrm{~N}_{9} \mathrm{O}_{3} \mathrm{Zn}, 783.168$.

Pc 3. The Boc group of Pc 2 was deprotected using TFA:DCM $(1: 1)$ at $0{ }^{\circ} \mathrm{C}$ for $4 \mathrm{~h}$. The solvents were removed under reduced pressure and the resulting residue was dissolved in dichloromethane/methanol (9:1). A few drops of $2 \mathrm{~N} \mathrm{NaOH}$ were added to neutralize TFA and the precipitate removed by filtration. The product was dried under vacuum for $2 \mathrm{~h}$ to give Pc $\mathbf{3}$ as a blue solid in quantitative yield. M.p.: $250{ }^{\circ} \mathrm{C} .{ }^{1} \mathrm{H}$ NMR $\left(D M F-d_{7}\right.$, $400 \mathrm{MHz}): 9.5$ (s, 2H, Ar-H), 8.3 (s, 2H, Ar-H), 7.97.5 (M, 14H, Ar-H), 6.9-6.8 (M, 4H, Ar-H). ${ }^{13} \mathrm{C} \mathrm{NMR}$ (DMF-d $\left.{ }_{7}, 100 \mathrm{MHz}\right): 153.4,139.1,138.7,138.7,130.0$, $128.8,122.4,122.2,120.9,117.1,116.4,115.2$. (Ar-C, 
Table 3. Major (+++) and Minor (+) subcellular sites of localization in HEp2 Cells

\begin{tabular}{ccccc}
\hline Pc & ER & Golgi & Mitochondria & Lysosomes \\
\hline $\mathbf{4}$ & ++ & ++ & - & +++ \\
$\mathbf{5}$ & ++ & +++ & + & +++ \\
$\mathbf{6}$ & + & +++ & - & +++ \\
$\mathbf{7}$ & +++ & +++ & - & +++ \\
\hline
\end{tabular}

CN). MS (MALDI- TOF) $\mathrm{m} / z[\mathrm{M}+\mathrm{H}]^{+}$684.172, calcd for $\mathrm{C}_{38} \mathrm{H}_{22} \mathrm{~N}_{9} \mathrm{OZn}, 684.124$.

Pc 4. Pc $3(50 \mathrm{mg}, 0.73 \mu \mathrm{mol})$ was dissolved in $100 \mu \mathrm{L}$ anhydrous DMF. 1, 1'-Thiocarbonyldi-2,2'pyridone $(16.9 \mathrm{mg}, 0.73 \mu \mathrm{mol})$ dissolved in DMF was added to the Pc solution and the final mixture stirred at room temperature for $6 \mathrm{~h}$. The solvent was removed under reduced pressure and the resulting residue was purified on silica gel preparative TLC plates using dichloromethane for elution, to give Pc 4 in $47.76 \mathrm{mg}$, $90 \%$ yield. M.p.: $180^{\circ} \mathrm{C} .{ }^{1} \mathrm{H}$ NMR (DMF-d $\left.{ }_{7}, 400 \mathrm{MHz}\right)$ : 8.17 (s, 2H, Ar-H), 7.51-7.46 (m, 9H, Ar-H), 6.38 (d, $J=$ $2.8 \mathrm{~Hz}, 4 \mathrm{H}, \mathrm{Ar}-\mathrm{H}), 6.21(\mathrm{t}, J=2.8 \mathrm{~Hz}, 4 \mathrm{H}, \mathrm{Ar}-\mathrm{H}) .{ }^{13} \mathrm{C}$ NMR (DMF-d, $100 \mathrm{MHz}): 149.9,149.6,149.3,141.0$, 136.0, 135.8, 135.5, 130.0, 123.8, 123.6, 123.3, 122.9, 120.6, 104.9, 93.6. MS (MALDI- TOF) $\mathrm{m} / \mathrm{z} .726 .0803$ $[\mathrm{M}+\mathrm{H}]^{+}$, calcd for $\mathrm{C}_{39} \mathrm{H}_{20} \mathrm{~N}_{9} \mathrm{OSZn}, 726.062$.
Pc 5. Pc $4(5 \mathrm{mg}, 6.896 \mu \mathrm{mol})$ was dissolved in $50 \mu \mathrm{L}$ DMF. Triethylamine $(0.523 \mathrm{mg}, 5.17 \mu \mathrm{mol})$ and ethanolamine $(0.316 \mathrm{mg}, 5.171 \mu \mathrm{mol})$ in $100 \mu \mathrm{L}$ DMF were added to the Pc $\mathbf{4}$ solution and the final mixture was stirred for $0.5 \mathrm{~h}$ at room temperature. The solvent was removed under reduced pressure, and the crude product purified by column chromatography using dichloromethane/methanol (9:1) for elution to give Pc 5 as a blue solid $(2.7 \mathrm{mg}, 66.41 \%)$. M.p.: $220^{\circ} \mathrm{C} .{ }^{1} \mathrm{H}$ (DMF$\left.\mathrm{d}_{7}, 400 \mathrm{MHz}\right): 8.3$ (m, 4H, Ar-H), 7.5 (m, 6H, Ar-H), 6.3 (s, 4H, Ar-H), 6.2 (s, 4H, Ar-H), 3.3 (m, 5H). ${ }^{13} \mathrm{C} \mathrm{NMR}$ (DMF-d $\mathrm{d}_{7}, 100 \mathrm{MHz}$ ): 161.3, 141.0, 135.7, 120.4, 104.8, 70.4, 60.5, 42.1, 40.5. MS (MALDI- TOF) $\mathrm{m} / \mathrm{z} 787.038$ $[\mathrm{M}+\mathrm{H}]^{+}$, calcd for $\mathrm{C}_{41} \mathrm{H}_{27} \mathrm{~N}_{10} \mathrm{O}_{2} \mathrm{SZn}, 787.133$.

Pc 6. Pc $4(5 \mathrm{mg}, 6.90 \mu \mathrm{mol})$ was dissolved in $100 \mu \mathrm{L}$ of DMSO. Biotin hydrazine $(1.98 \mathrm{mg}, 6.90 \mu \mathrm{mol})$ and triethylamine $(28.85 \mu \mathrm{L}, 207 \mathrm{mmol})$ in $50 \mu \mathrm{L}$ DMSO were added to the Pc $\mathbf{4}$ solution. The final mixture was stirred for $2 \mathrm{~h}$ at room temperature. The crude product was precipitated out of solution by the addition of diethyl ether. The residue was re-dissolved in dichloromethane/ methanol (9:1) and washed once with water. The organic phase was dried over anhydrous $\mathrm{Na}_{2} \mathrm{SO}_{4}$ to give Pc 6 as a blue compound $(4.74 \mathrm{mg}, 70 \%)$. M.p.: $190{ }^{\circ} \mathrm{C} .{ }^{1} \mathrm{H}$ NMR (DMSO-d ${ }_{6}$ ): 9.5-9.45 (6H, Ar-H), 8.3-8.3 (m, 6H, Ar-H), 7.8 (d, 1H, Ar-H), 7.66 (m, 2H, Ar-H), 7.5-7.4 (m, 5H, Ar-H), 6.3 (m, 2H, Ar-H), 6.2-6.1 (m, 2H, Ar-H), $4.1(\mathrm{br}, 2 \mathrm{H}), 3.6(2 \mathrm{H}), 3.3(3 \mathrm{H}), 3.1-3.0(1 \mathrm{H}), 1.6(1 \mathrm{H})$, (a)

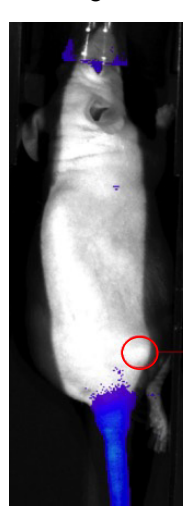

3

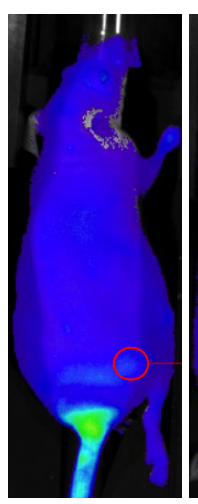

6

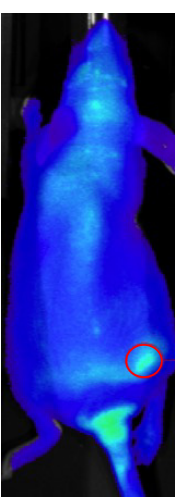

24

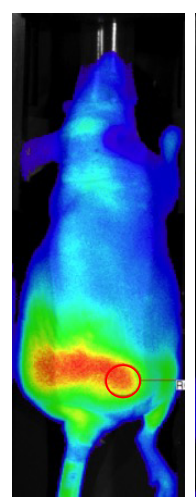

48

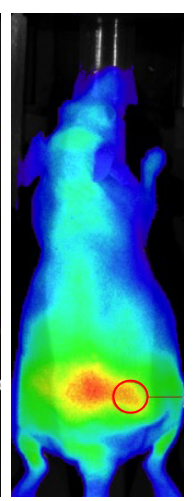

72

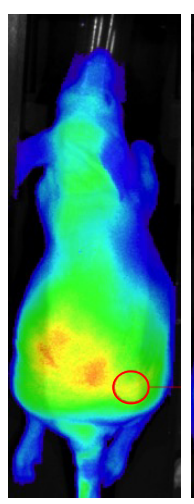

120

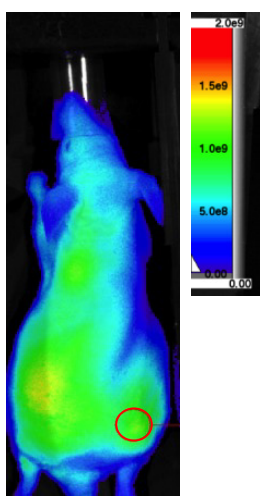

(b)

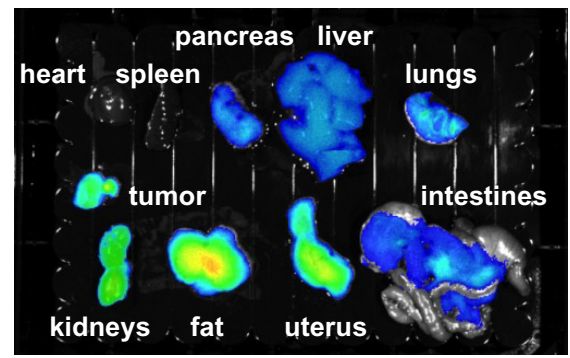

Fig. 7. (a) Fluorescence images (excitation $640 \mathrm{~nm}$ and emission $710 \mathrm{~nm}$ ) of a nude mouse bearing subcutaneous HT-29 tumor implants at $0,3,6,24,48,72$, and $120 \mathrm{~h}$ following i.v administration of Pc 6. The tumor position is circled. (b) Fluorescence images (excitation $640 \mathrm{~nm}$ and emission $710 \mathrm{~nm}$ ) of organ and tumor tissues harvested from the mouse after the final imaging time point 
$1.3(5 \mathrm{H}), 0.9(1 \mathrm{H}) .{ }^{13} \mathrm{C}$ NMR (DMSO-d $\left.6,100 \mathrm{MHz}\right)$ : 149.9, 149.6, 149.3, 147.2, 141.0, 138.8, 136.0, 135.6, $135.7,135.5,130.0,123.8,123.6,123.3,122.8,120.6$, $115.2,111.0,110.1,104.9,93.6,90.6,90.3,55.0,49.1$, 40.4, 20.0. MS (MALDI- TOF) $\mathrm{m} / z$ 1006.190 $[\mathrm{M}+\mathrm{Na}]^{+}$, calcd for $\mathrm{C}_{49} \mathrm{H}_{37} \mathrm{~N}_{13} \mathrm{O}_{3} \mathrm{~S}_{2} \mathrm{Zn}, 1006.177$.

Pc 7. Pc 4 (10 mg, $0.14 \mu \mathrm{mol})$ was dissolved in $100 \mu \mathrm{L}$ of DMF. Biotin ethylenediamine $(7.89 \mathrm{mg}, 0.28 \mu \mathrm{mol})$ was dissolved in $200 \mu \mathrm{L}$ DMSO and triethylamine (41.87 $\mathrm{mg}, 0.41 \mathrm{mmol}$ ) was added onto this before adding this mixture to the Pc 4 solution. The solvent was removed. The crude in dichloromethane/methanol 9:1 was purified on silica gel TLC preparative plates to give title Pc 7 (16.74 mg, 60\%). M.p.: $170{ }^{\circ} \mathrm{C} .{ }^{1} \mathrm{H}$ NMR $\left(\mathrm{DMSO}_{6}\right)$ : 9.3-9.1 (m, 5H, Ar-H), 8.2-8.1 (m, 7H, Ar-H), 7.6-7.5 (m, 3H, Ar-H), 7.2-7.0 (m, 1H, Ar-H), 3.8-3.7 (m, 5H), $3.5(\mathrm{~m}, 2 \mathrm{H}), 3(\mathrm{~m}, 2 \mathrm{H}), 2.4(\mathrm{~m}, 1 \mathrm{H})$, 2.3-2.1 (m, 4H), 1.8-1.5 (m, 7H), $1.5(\mathrm{~b}, 2 \mathrm{H}), 1(\mathrm{~m}, 1 \mathrm{H})$ ${ }^{13} \mathrm{C}$ NMR (DMSO-d 6 , $100 \mathrm{MHz}$ ): 162.6, 162.3, 162.0, 149.9, 149.6, 123.9, 123.6, 123.4, 55.0, 35.4, 35.2, 35.0, 34.8, 34.6, 34.4, 34.2, 30.3, 30.1, 29.9, 29.7, 29.5, 29.3, 29.1. MS (MALDI-TOF) $\mathrm{m} / \mathrm{z} 1050.097[\mathrm{M}]^{+}$, calcd for $\mathrm{C}_{51} \mathrm{H}_{41} \mathrm{~N}_{13} \mathrm{O}_{3} \mathrm{~S}_{2} \mathrm{ZnK}, 1050.182$.

\section{Spectroscopic properties}

All studies were performed in peptide-sequencing grade DMF solutions. All absorption spectra were measured on a UV-vis Perkin Elmer Lambda 35 spectrophotometer. All experiments were carried out within $3 \mathrm{~h}$ of solution preparation at room temperature (23$25^{\circ} \mathrm{C}$ ) using a $10 \mathrm{~mm}$ path length spectrophotometric cell. Emission spectra were recorded on a Fluorolog ${ }^{\circledR}$ HORIBA JOBINVYON (Model LFI-3751). The fluorescence quantum yields $\left(\Phi_{\mathrm{f}}\right)$ were determined via a secondary standard method using $\mathrm{ZnPc}\left(\Phi_{\mathrm{f}}=0.17\right)$ as the Ref. [45].

\section{Cell studies}

The HEp2 cells were obtained from ATCC and maintained in a $75 \mathrm{~cm}^{2}$ flask (Chemglass) with medium (DMEM:Advanced, 1:1) containing 10\% FBS and 1\% antibiotic (Life Technologies). The Pc solutions were prepared by dissolving each Pc in 100\% DMSO at a concentration of $32 \mathrm{mM}$ (stock solution).

Dark cytotoxicity. The HEp2 cells were placed in a Costar 96-well plate (15,000 cells/well). Each plate was treated with Pc concentrations of 200, 100, 50, 25, 12.5, and $0 \mu \mathrm{M}$ for $0-24 \mathrm{~h}$ incubation at $37^{\circ} \mathrm{C}$. To end treatment, excess Pc was removed by washing cells with PBS and replaced with media containing 20\% Cell Titer Blue (Promega). The cells were incubated for an additional $4 \mathrm{~h}$ at $37^{\circ} \mathrm{C}$, and measured fluorescently at $570 / 615 \mathrm{~nm}$ using a FluoStar Optima micro-plate reader. Dark toxicity is expressed in terms of percent survival of cells.

Phototoxicity. The Pc concentrations of 100, 50, $25,12.5,6.25,3.125$, and $0 \mu \mathrm{M}$ were used for the phototoxicity experiments. HEp2 cells were placed in 96 well plates as described above, and treated with the Pc solutions for $24 \mathrm{~h}$ at $37^{\circ} \mathrm{C}$. After this treatment the loading media was removed. The cells were washed with a PBS buffer, and then refilled with fresh media. The cells were exposed to a $600 \mathrm{~W}$ halogen lamp light source filtered with a water filter and a beam turning mirror (Newport) for $20 \mathrm{~min}$. The total light dose was approximately $1.5 \mathrm{~J} / \mathrm{cm}^{2}$. After being exposed to light, the cells were returned to the incubator for $24 \mathrm{~h}$. After $24 \mathrm{~h}$ incubation, the medium was removed and replaced with media containing 20\% Cell Titer Blue. The cells were incubated for an additional $4 \mathrm{~h}$. The viable cells were measured fluorescently at 570/615 nm using a FluoStar Optima micro-plate reader. Phototoxicity is expressed in terms of percent survival of cells.

Time-dependent cellular uptake. The HEp2 cells were plated in a 96-well plate as described above. The cells were treated by adding $100 \mu \mathrm{L}$ of $10 \mu \mathrm{M}$ Pc solution at different time periods of $0,1,2,4,8$, and $24 \mathrm{~h}$. The cells were washed with PBS, and solubilized by adding $100 \mu \mathrm{L} 0.25 \%$ Triton X-100 in PBS per well. The cells were quantified by CyQuant Cell Proliferation Assay (Life Technologies). The compound and cell number were determined using a FluoStar Optima microplate reader. Cellular uptake is expressed in terms of $\mathrm{nM} \mathrm{Pc}$ concentration per cell.

\section{In vivo studies}

For the in vivo studies, athymic nu/nu mice (Charles River Laboratories, Wilmington MA) were purchased at six weeks of age and quarantined for one week. Subsequently, the human colorectal adenocarcinoma HT-29 cell line (ATCC; Manassas, VA) was implanted subcutaneously in the lower right flank. Initially, HT-29 cells were cultured in McCoy's 5A medium containing $10 \%$ fetal bovine serum (Atlanta Biologicals; Flowery Branch, GA) and incubated at $37^{\circ} \mathrm{C}$ and $5 \% \quad \mathrm{CO}_{2}$ under humidified conditions to approximately $75 \%$ confluence. The cells were then harvested with a $0.25 \%$ (w/v) trypsin - $0.53 \mathrm{mM}$ EDTA solution, concentrated via centrifugation, and resuspended in Dulbecco's PBS before injection. Each of the mice was injected with $5 \times 10^{6}$ cells in $0.1 \mathrm{~mL}$ PBS. Tumors were allowed to develop until approximately $5 \mathrm{~mm}$ in diameter, after which mice were subjected to lateral tail vein injection of the Pc conjugate resuspended at $2 \mathrm{mM}$ in Dulbecco's PBS containing 10\% DMSO and 5\% Kolliphor EL (Sigma-Aldrich, St. Louis, MO). After injection, the mice were observed for any acute adverse responses and then anesthetized using 3\% isoflurane for imaging. Fluorescence imaging was performed at $0,3,6,24,48$, 72 , and $120 \mathrm{~h}$ after injection using a Spectral AMI optical imaging system (Spectral Instruments Imaging; Tucson, AZ) set at an excitation $640 \mathrm{~nm}$ and emission $710 \mathrm{~nm}$. All experimental protocols involving live animals were 
reviewed and approved by the Institutional Animal Care and Use Committee (IACUC) of LSU.

\section{CONCLUSIONS}

We describe the synthesis of an isomerically pure $\mathrm{A}_{3} \mathrm{~B}$-type $\mathrm{Pc}$ functionalized with an isothiocyanate group, Pc 4, in $11 \%$ overall yield. The strategy involves the condensation of a Boc-protected amino phthalonitrile with a large excess (30-fold) of phthalonitrile, followed by deprotection with TFA and reaction with TDP. The highly reactive isothiocyanate functional group readily reacts with primary amines under mild conditions and in high yields. Using this strategy, three new Pcs were prepared bearing ethanolamine, biotin hydrazine or biotin ethylenediamine, in 60-75\% yields. These amphiphilic conjugates showed enhanced solubility and uptake into human carcinoma HEp2 cells. In DMF solutions the Pcs show absorption and emission spectra typical of Pc macrocycles, and fluorescence quantum yields in the range 0.18-0.27. All Pcs were non-toxic in the dark up to $200 \mu \mathrm{M}$ concentrations, but displayed significant phototoxicity, with $\mathrm{IC}_{50}$ values in the order of $7 \mu \mathrm{M}$ using $1.5 \mathrm{~J} / \mathrm{cm}^{2}$ light dose. The biotin-Pc 6 was further investigated in a mouse model bearing a HT-29 tumor. This conjugate was found to selectively localize within tumors as soon as $6 \mathrm{~h}$ after i.v. administration via the tail vein. Our results demonstrate that the isomerically pure isothiocyanate-functionalized Pc $\mathbf{4}$ is an excellent template for the synthesis of tumor cell-targeted amphiphilic Pc analogs in good overall yields and under mild conditions.

\section{Acknowledgments}

This research was funded by the National Institutes of Health, grant number R01 CA179902.

\section{Supporting information}

Absorption spectra, dark toxicity and phototoxicity (Figs S1-S6) are given in the supplementary material. This material is available free of charge via the Internet at http://www.worldscinet.com/jpp/jpp.shtml.

\section{REFERENCES}

1. Sharma D, Huijser A, Savolainen J, Steen G and Herek JL. Faraday Discuss. 2013; 163: 433-445.

2. Vakoulovskaya EG, Shental VV, Oumnova LV and Vorozhcsov GN. Proceedings of the SPIE 2003; 4952: 149-151.

3. Baron ED, Malbasa CL, Santo-Domingo D, Fu P, Miller JD, Hanneman KK, Hsia AH, Oleinick NL, Colussi VC and Cooper KD. Lasers Surg. Med. 2010; 42: 728-735.

4. Sekkat N, van den Bergh $\mathrm{H}$, Nyokong $\mathrm{T}$ and Lange N. Molecules 2011; 17: 98-144.
5. Weissleder R and Ntziachristos V. Nat. Med. 2003; 9: $123-128$.

6. Ntziachristos V, Bremer C and Weissleder R. Eur. Rad. 2003; 13: 195-208.

7. Luo S, Zhang E, Su Y, Cheng T and Shi C. Biomaterials 2011; 32: 7127-7138.

8. Ongarora BG, Hu X, Verberne-Sutton SD, Garno JC and Vicente MGH. Theranostics 2012; 2: 850-870.

9. Vrouenraets MB, Visser GW, Stigter M, Oppelaar $\mathrm{H}$, Snow GB and van Dongen GA. Cancer Res. 2001; 61: 1970-1975.

10. Vrouenraets MB, Visser GW, Stigter M, Oppelaar $\mathrm{H}$, Snow GB and van Dongen GA. Int. J. Cancer 2002; 98: 793-798.

11. Duan W, Smith K, Savoie H, Greenman J and Boyle RW. Org. Biomol. Chem. 2005; 3: 2384-2386.

12. Ke MR, Yeung SL, Fong WP, Ng DK and Lo PC. Chem. -Eur. J. 2012; 18: 4225-4233.

13. Rodriguez ME, Zhang P, Azizuddin K, Delos Santos GB, Chiu SM, Xue LY, Berlin JC, Peng X, Wu H, Lam M, Nieminen AL, Kenney ME and Oleinick NL. Photochem. Photobiol. 2009; 85: 1189-1200.

14. Ongarora BG, Zhou Z, Okoth EA, Kolesnichenko I, Smith KM and Vicente MGH. J. Porphyrins Phthalocyanines 2014; 18: 1021-1033.

15. Göksel M. Bioorg. Med. Chem. 2016; 24: 4152-4164.

16. Hammer RP, Owens CV, Hwang SH, Sayes CM and Soper SA. Bioconjugate Chem. 2002; 13: 1244-1252.

17. López-Duarte I, Dieu LQ, Dolamic I, MartínezDíaz MV, Torres T, Calzaferri G and Brühwiler D. Chem. -Eur. J. 2011; 17: 1855-1862.

18. Li H, Fronczek FR and Vicente MGH. Tetrahedron Lett. 2008; 49: 4828-4830.

19. Zorlu Y, Dumoulin F, Bouchu D, Ahsen V and Lafont D. Tetrahedron Lett. 2010; 51: 6615-6618.

20. Vrouenraets MB, Visser GWM, Stewart FA, Stigter M, Oppelaar H, Postmus PE, Snow GB and van Dongen GAMS. Cancer Res. 1999; 59: 1505-1513.

21. Carcenac M, Larroque C, Langlois R, van Lier JE, Artus JC and Pelegrin A. Photochem. Photobiol. 1999; 70: 930-936.

22. Sehgal I, Li H, Ongarora BG, Devillier D and Vicente MGH. J. Porphyrins Phthalocyanines 2013; 17: 150-156.

23. Leznoff CC and Sosa-Sanchez JL. Chem. Commun. 2004; 0: 338-339.

24. Li XY and Ng DKP. Tetrahedron Lett. 2001; 42: 305-309.

25. Josefsen LB and Boyle RW. Br. J. Pharmacol. 2008; 154: $1-3$.

26. Hellebust A and Richards-Kortum R. Nanomedicine (London) 2012; 7: 429-445.

27. Carcenac M, Dorvillius M, Garambois V, Glaussel F, Larroque C, Langlois R, Hynes NE, van Lier JE and Pèlegrin A. Br. J. Cancer 2001; 85; 1787-1793. 
28. Moret F and Reddi E. J. Porphyrins Phthalocyanines 2017; 21: 239-256.

29. Russell-Jones G, McTavish K, McEwan J, Rice $\mathrm{J}$ and Nowotnik D. J. Inorg. Biochem. 2004; 98: 1625-1633.

30. Tripodo G, Mandracchia D, Collina S, Rui M and Rossi D. Med. Chem. 2014; 8, 1-4.

31. Sibrian-Vazquez M, Ortiz J, Nesterova IV, Fernández-Lázaro F, Sastre-Santos A, Soper SA and Vicente MGH. Bioconjugate Chem. 2007; 18: 410-420.

32. Chen S, Zhao X, Chen J, Chen J, Kuznetsova L, Wong SS and Ojima I. Bioconjugate Chem. 2010; 21: 979-987.

33. Li X, Kim CY, Lee S, Lee D, Chung HM, Kim G, Heo SH, Kim C, Hong KS and Yoon J. J. Am. Chem. Soc. 2017; 139: 10880-10886.

34. Stallivieri A, Baros F, Jetpisbayeva G, Myrzakhmetov B and Frochot C. Curr. Med. Chem. 2015; 22: 3185-3207.

35. Meerovich IG, Jerdeva V, Derkacheva VM, Meerovich GA, Lukyanets EA, Kogan EA and Savitsky AP. J. Photochem. Photobiol. B 2005; 80: 57-64.
36. Sutton JM, Clarke OJ, Fernandez N and Boyle RW. Bioconjugate Chem. 2002; 13: 249-263.

37. Hudson R, Carcenac M, Smith K, Madden L, Clarke OJ, Pèlegrin A, Greenman J and Boyle RW. Br. J. Cancer 2005; 92: 1442-1449.

38. Sibrian-Vazquez M, Jensen TJ, Fronczek FR, Hammer RP and Vicente MGH. Bioconjugate Chem. 2005; 16: 852-863.

39. Clarke OJ and Boyle RW. Chem. Commun. 1999; 0: 2231-2232.

40. Soini AE, Yashunsky DV, Meltola NJ and Ponomarev GV. Luminescence 2003; 18: 182-192.

41. Malatesti N, Smith K, Savoie H, Greenman J and Boyle RW. Int. J. Oncol. 2006; 28: 1561-1569.

42. Kim S and Yi KY. J. Org. Chem. 1986; 51: 2613-2615.

43. Ongarora BG, Hu X, Li H, Fronczek FR and Vicente MGH. MedChemComm 2012; 3: 179-194.

44. Chaudhary PM, Murthy RV, Yadav R and Kikkeri R. Chem. Commun. 2015; 51: 8112-8115.

45. Zorlu Y, Dumoulin F, Durmuş M and Ahsen V. Tetrahedron 2010; 66: 3248-3258. 